DOI: $10.17976 / j p p s / 2018.06 .11$

\title{
ИСТОРИЗМ И АПРИОРИЗМ: ПОЛИТИКО-АНАЛИТИЧЕСКАЯ РЕТРОСПЕКТИВА РУССКОЙ РЕВОЛЮЦИИ
}

\section{B.Г. Хopoc}

ХОРОС Владимир Георгиевич, доктор исторических наук, руководитель Центра проблем развития и модернизации, ИМЭМО им. Е.М. Примакова РАН, Москва. Для связи с автором: khoros@imemo.ru

Хорос В.Г. Историзм и априоризм: политико-аналитическая ретроспектива Русской революции. Полис. Политические исследования. 2018. № 6. С. 155-171. https://doi.org/10.17976/jpps/2018.06.11

Статья поступила в редакцию: 23.04.2018. Принята к печати: 18.07.2018

Аннотация. Статья инициирована авторской рефлексией по прочтении серии статей, посвященных столетию годовщины Октябрьской революции 1917 г. в России и опубликованных в специальном выпуске журнала "История и современность” (2017, № 2). Эти статьи в целом отражают отношение к данному крупному историческому событию как в российском обществе, так и в академических кругах. Здесь можно выделить два основных подхода. В первом случае признается, что к революции привели прежде всего объективные факторы, которые в значительной мере были уже выявлены предшествующей историографией. Для второго подхода характерен поиск новых интерпретаций, причем обосновывающих негативный взгляд на 2017 г. При этом зачастую нарушается принцип историзма, т.е. понимания, почему акторы в специфических условиях прошлого мыслили и действовали так, а не иначе, и только после этого и на основании этого возможна их научная и моральная оценка. Характеристика Октябрьской революции во многом зависит от отношения к ее результатам, советской эпохе российской истории. Автор предлагает свой взгляд на советский период в контексте общемировой эволюции социализма. Главная идея состоит в том, чтобы понимать советский социализм как многосторонний феномен, который нельзя сводить лишь к негативным аспектам. Такой же подход необходим и по отношению к революции(ям) 1917 года.

Ключевые слова: российская революция 1917 г.; социализм; идеология; принцип историзма; априоризм; советская эпоха.

К революции (и революциям) 1917 г., столетие которой тихо миновало в конце прошлого года, можно относиться по-разному. Но любая серьезная оценка должна базироваться на принципе историзма. Последний предполагает понимание - проникновение в то, почему и с какими критериями действовали или могли действовать акторы в прошлом “в предлагаемых обстоятельствах" - в отличие от последующих поколений, располагающих уже иными “предлагаемыми обстоятельствами” и критериями. Понимание того, насколько те или иные действия или лозунги были связаны с тогдашней исторической ситуацией, с тем или иными объективными факторами. И только на основании такого анализа можно давать оценку - политическую и/или моральную - деятелям прошлого. Если игнорировать эти принципы исторического знания, оно превращается в нечто вроде школьного табеля, в котором выставляются отметки в диапазоне “хорошо - плохо". При этом стоит помнить, что морально-эмоциональный и научный подход не вполне совпадают, хотя и не противоположны друг другу. 
На фоне довольно скудной реакции в нашем Отечестве (не берусь дать оценку откликам за рубежом) на историческое событие всемирного значения, “набравшее” столь круглую дату, хотелось бы отдать должное журналу “История и современность” ", посвятившему специальный выпуск российской революции 1917 г., попыткам осмыслить ее с вековой исторической дистанции. Эта инициатива дорогого стоит. Конечно, какие-то статьи по случаю юбилейной даты печатались и в других журналах, проводились какие-то научные конференции. Но в целом внимания к столь крупному юбилею было проявлено гораздо меньше, чем ожидалось и чем он того заслуживал. Ощущалось стремление замолчать тему или по крайней мере минимизировать ее освещение. Официальная позиция (если о ней вообще можно говорить) была невнятной и скорее безразличной (см. например [Малинова 2018]). В том же, что попало на страницы журналов, а особенно газет и на телевидение, доминировали негативные оценки: “катастрофа”, “политический переворот”, "русская трагедия” и подобное. А в телепередаче "Агора" от представителей исторической науки прозвучало даже заявление, что Октябрьскую революцию сделали “уголовные преступники”.

Помещенные в специальном выпуске журнала статьи условно можно разделить на три группы. Первую группу составляют материалы, имеющие довольно косвенное отношение к собственно революционным событиям 1917 г. В статье В.В. Канищева и Н.С. Цинцадзе “Социоестественные аспекты российской революции 1917 года” рассматриваются экологические и природоохранные аспекты аграрной политики российских и затем советских властей, что объясняется желанием редакции не терять связь с традиционным для данного журнала направлением "социоестественной истории”. Точно так же статья И.И. Баринова “Ирредентизм и трансформация имперской идентичности: Остзейский край в событиях 1917 г.” достаточно далека от проблематики российской революции, хотя и затрагивает важные моменты политической жизни этого региона в период его радикальной трансформации, инициированной революционными событиями 1917 г. Этих текстов я касаться не буду. Другие статьи объединяет то, что хотя их авторы стремятся внести (каждый свою) лепту в понимание революции 1917 г., но при этом все же принимают некоторые наработанные, утвердившиеся подходы к данной тематике. Наконец, третью группу составляют статьи, где авторы ставят целью осветить предмет по-новому, не сверяясь со своими предшественниками или даже противореча им (другой вопрос, насколько убедительно это получается). В таком порядке эти две группы статей я и буду рассматривать.

A.Э. Айвазов и В.А. Беликов исходят из неслучайности и объективности Октябрьской революции. Такой взгляд распространен, но в последнее время он стал подвергаться сомнению². Авторы статьи акцентируют значение аграрной проблемы в российской революции. Они считают Октябрь 1917 г.

\footnotetext{
1 “История и современность”. Специальный выпуск к 100-летию Русской революции. 2017. № 2.

2 Показательна позиция петербургского историка Б.Н. Миронова [Миронов 2003; 2010; 2014]. Кратко суть ее в следующем: неверен тезис об ухудшении материального положения трудящихся пореформенной России как причине революций 1917 г., хотя, безусловно, социальные и экономические предпосылки для революционного разрешения политического кризиса в России существовали. Но главным двигателем революции, по Б.Н. Миронову, стало “нетерпение” оппозиционных элит, которые в конце концов раскачали политическую ситуацию в стране. Впрочем, на это можно возразить следующее. Роль элит (или контрэлит) в политической борьбе бесспорна, но в этой борьбе элиты как раз и озвучивают те или иные интересы и требования масс, а эти интересы и требования возникают из объективной ситуации в обществе, экономического, социального и культурного исторического контекста (подробнее см. [Хорос 2010; 2016]).
} 
“аграрно-крестьянской революцией” [Айвазов, Беликов 2017: 148]. На мой взгляд, это слишком резкая формулировка - Октябрьская революция имеет и другие коннотации. Но несомненно, крестьянский вопрос стал мощным катализатором революционных событий семнадцатого года.

Авторы рассматривают крестьянскую реформу 1861 г. в России и гомстед-акт в США как примеры двух принципиально различных моделей аграрных преобразований. Они справедливо указывают на минусы и изъяны “Великого освобождения” крестьян в России (отрезки, затянутость временнообязанного состояния, тяжесть выкупной операции, легшей на плечи крестьян, пережитки крепостничества, сохранение крупного помещичьего землевладения), обусловившие серьезные проблемы пореформенной деревни, рост антипомещичьих настроений, и в конце концов - революционные потрясения начала ХХ в. Напротив, гомстед-акт в США открыл дорогу бурному развитию сельского хозяйства и прогрессу капитализма.

С этим, казалось бы, можно согласиться. Но был ли у России выбор? В российских условиях XIX в. не было шансов на осуществление чего-то подобного гомстед-акту. Для этого не имелось (особенно в центральной России) достаточно земли, а власть стояла на страже интересов помещиков. Подход А.Э. Айвазова и В.А. Беликова по большому счету не нов. Еще В.И. Ленин указывал на то, что 1861 г. породил и 1905 г., и 1917 г., и он же противопоставлял “американский” и “прусский" пути развития капитализма (в последнем случае имея в виду, конечно, Россию). Говорю это вовсе не в упрек авторам статьи. Повторять верные идеи, сегодня во многом забытые, и полезно, и нужно.

Л.Е. Гринин анализирует российскую революцию в свете теории модернизации. Он полагает закономерным “рост революционных настроений в обществе” накануне 1917 г. “...Основной причиной русских революций было то, что модернизирующееся общество, каким являлась Российская империя, в условиях быстрой урбанизации и демографического роста неизбежно сталкивается с сильными деформациями и изменениями, которые обостряют все противоречия в обществе... Революции в России были почти неизбежны. Однако результаты революций не были неизбежными, а зависели от баланса сил и исторической обстановки в период их назревания" [Гринин Л. 2017: 50]. Сравнивая различные революции XVIII-XX вв. и масштабы вызванных ими общественных потрясений, автор подчеркивает, что “социальная ломка в Русской революции была особенно долгой по сравнению с предшествующими” [там же: 26]. Эта ее особенность нуждается в разъяснении.

Объяснительные возможности теории модернизации в последнее время все чаще используются в отечественной науке, и, пожалуй, можно признать, что эта концепция лучше объясняет революционные процессы, чем формационная теория. Модернизация как процесс перехода от традиционного, аграрного общества к современному, индустриальному захватывает все сферы общества - экономическую, социальную, политическую, правовую и культурно-цивилизационную. Те или иные этапы этого процесса сопровождаются революциями - что, собственно, и имело место в России в начале XX в.

Л.Е. Гринин излагает свое понимание теории модернизации, которое, на мой взгляд, порой выглядит не вполне ясным и избыточно громоздким. Так, он описывает разнообразные “ловушки" на пути модернизации - мальтузианскую, “марксову” (т.е. классовую борьбу), урбанистическую, молодежную, а для России еще и “мальтузианско-марксову”. Его основной тезис справед- 
лив: революции могут происходить вследствие не только неудач модернизации, но и ее успехов, что "работает" и применительно к случаю России. Здесь со второй половины XIX в. промышленный прогресс, рост урожайности, распространение грамотности и т.д. сопровождались усилением социального расслоения, диспропорциями между городом и деревней, ухудшением жизни “значительной части населения”, несоответствием реальности и социальнопсихологических ожиданий, “когда то, что раныше казалось естественным и неизбежным, теперь стало казаться невыносимым” [там же: 43]. Иначе говоря, социальные, политические и правовые изменения в России отставали от изменений экономических, модернизация протекала не системно. Это вполне согласуется с тезисом, высказанным еще в ранней работе С. Хантингтона: успехи модернизации сопровождаются растущей конфликтностью в обществе, и может существовать “прямая связь (apparent association) между быстрым экономическим ростом и политической нестабильностью” [Huntington 1968: 51]. Примерно к этому же выводу приходит Б.Н. Миронов, также использующий концепт модернизации применительно к России [Миронов 2010: 670].

Что же касается “социальных издержек” революции 1917 г. и последовавшего за ней долгого периода "социальной ломки”, то Л.Е. Гринин объясняет это особыми условиями того времени, прежде всего разрушительными последствиями войны и выходом армии из-под контроля правительства. Поэтому “с какого-то периода в 1917 г.” радикализации революции и длительной социальной ломки “уже было не избежать” [Гринин Л. 2017: 52]. Однако возникает вопрос: имело ли то, что произошло после Октябрьской революции, отношение к модернизации или было отходом от нее?

Л.Е. Гринин этот вопрос прямо не ставит, но, исходя из некоторых его суждений, можно предположить, что модернизации способствовали только те революции, “которые совершаются уже в конце полосы модернизации и преобразований", либо же, "хотя это и звучит неожиданно, революции, потерпевшие поражение”. Последние, "не позволяя разрушить общество до основания, становятся теми драйверами, которые заставляют правительства реформировать политическую и социальную систему". Таковы, по его мнению, революции 1848-1849 гг. в Европе и революция 1905-1907 гг. в России [там же: 51]. Октябрьская же революция и последовавшие за ней “социальные эксперименты потребовали очень высокой цены от СССР и последовавших за ним социумов". Даже с учетом того, что "на определенном этапе развития советское общество цивилизовалось и добилось довольно значительных успехов”, все равно - и "обидно" - “что этот путь оказался тупиковым" [там же: 28].

Я еще вернусь к этой теме, к обсуждению результатов и “тупиковости" революционных социалистических преобразований в России. Пока лишь в порядке констатации - скажу, что планетарный процесс модернизации шел неравномерно и в мировом пространстве, и в историческом времени. Он имел свои стадии и, так сказать, эшелоны. В первом эшелоне, странах Запада, модернизация протекала относительно постепенно и органично, новые институты вырастали из институтов традиционного общества (хотя, конечно, имели место и конфликты, революции). Именно здесь складывались модели капитализма и демократии в классическом варианте. Но уже второй эшелон модернизации (Россия, Япония, Турция, некоторые восточноевропейские и латиноамериканские страны) имел существенные отличия от первого. Это и более поздний и форсированный приступ к модернизации (в силу приме- 
ра извне и внешней угрозы), и менее развитые предпосылки для изменений в традиционном обществе, особо значимая роль государства в осуществлении модернизации, различные его авторитарные формы. Эти отличия еще более давали о себе знать в третьем эшелоне модернизации - колониальных и зависимых странах. Таким образом, процесс модернизации протекал в "запоздавших" странах более конфликтно и, соответственно, более “социально затратными” были здесь революции и радикальные реформы. Одна из разновидностей такой модернизации - ее социалистический вариант: сначала в России, а затем в ряде других стран (подробнее см. [Хорос 1994: 10-18]).

Отождествима ли модернизация лишь с ее западной моделью, является ли ее социалистический вариант историческим тупиком? Думается, что история еще не дала ответ на этот вопрос. Посмотрим, что покажет Китай, где нет демократии европейского типа. Возможны и какие-то другие случаи. Полагаю также, что вряд ли можно отрицать модернизационные процессы в советском обществе, хотя какие-то институты (прежде всего политические) были тормозом на этом пути.

Теперь о третьей группе статей, которых оказалось гораздо больше. Как уже говорилось, их отличает стремление к инновационной трактовке причин, характера и последствий российских революций 1917 г. Сам по себе такой исследовательский настрой можно только приветствовать. Но при этом важно, чтобы увлеченность автора своей идеей не привела к простой подгонке под нее исторического материала, чтобы учитывались pro et contra, аргументы "за" и возможные возражения “против” выдвинутой трактовки. Иначе результат получится недостаточно убедительным.

Ю.C. Оганисьян в своей статье подходит к Октябрьской революции и последовавшим за ней событиям под углом зрения представлений о терроризме, который при этом подчас понимается слишком широко. В статье объединены два самостоятельных сюжета. Во-первых, анализ террора ВЧК и разведки белых армий в период гражданской войны. Полагаю, применительно к эпохе революции и гражданской войны в России имеет смысл говорить о терроризме лишь в узком смысле - об акциях устрашения, массовых расстрелах, показательных арестах и пр. Очень часто их связывают преимущественно с большевиками (“красный террор”). Ю.С. Оганисьян прав в том, что гражданская война создала “порочный круг” террора, и соответствующие действия противоположных сторон друг друга стоили [Оганисьян 2017: 169-174]. Следует, наверное, обратить внимание на появляющиеся в научной литературе соображения о том, что большевики не были закоперщиками гражданской войны. Так, в 1918 г. советская власть еще настраивалась на мирную перспективу - были открыты 33 научных института, разрабатывались планы экономического и культурного строительства. Аппарат ВЧК составлял всего 120 человек. Инициатива конфронтации исходила по большей части с другой стороны - отказ меньшевиков и эсеров от сотрудничества, чехословацкий мятеж, снабжение военно-промышленными комитетами армии Деникина, восстание Каледина.

Есть в статье и вторая сюжетная линия: анализ природы современного терроризма - от “красных бригад” в Италии, латиноамериканских "Сендеро луминосо”, ирландских боевиков, баскских сепаратистов до исламских террористов в Алжире, Сирии, Ираке... Объединяет эти два сюжета, по словам автора, “единый социально-исторический контекст послеоктябрьской эпохи", единство которого в том, что “как и столетие назад, он постоянно воспроизводится противоречиями между финансово-олигархическими группи- 
ровками и народными массами в национальном и международном масштабе" [там же: 178]. Эта общая скобка мало что дает, и непонятно, где в перипетиях гражданской войны в России можно усмотреть противостояние “финансовоолигархических группировок” и “народных масс". Общий пафос статьи поэтому получился скорее морального, нежели научного характера: Октябрьская революция - это “неусвоенные уроки” для современного человечества, ибо "любой общественный строй, каким бы справедливым он ни изображался его апологетами, обречен на вырождение, если он базируется на насилии" [там же: 175].

Что сближает европейскую Реформацию и российскую революцию? На этот вопрос пытается дать ответ C.B. Цирель, сам заголовок статьи которого уже интригует - “Революция 1917 года как альтернатива несостоявшейся Реформации”. Автор помещает в некий общий “контекст” (опять “единый исторический контекст") "европейскую Реформацию, революцию 1917 г. в России и нынешний исламизм, включая как Иранскую революцию 1979 г., так и образование запрещенных в РФ 'Аль-Каиды' и ИГИЛ” [Цирель 2017: 60]. Так и хочется сказать, перефразируя Достоевского: широк подход, я бы сузил...

У такого подхода есть предшественники - немецкий автор Г. Рормозер и россияне В.Д. и 3.Р. Жукоцкие. Правда, С.В. Цирель не во всем согласен с ними, в частности, не принимает интерпретацию Ленина как реинкарнации Лютера. Тем не менее для него аналогия между Реформацией и Октябрьской революцией имеет смысл, поскольку в начале XX в. Россия испытывала не только материальные, социально-экономические трудности, но и духовный кризис. Требовалась новая вера, “ожидаемая Реформация”, которая была вызвана, “как и в Европе, ростом грамотности, расширением контактов крестьян с окружающим миром, неудовлетворенностью христианско-языческим двоеверием” [там же: 73]. Проявлялось это “ожидание” по-разному - и в “массовой индифферентности к религии”, и, напротив, в росте сектантства, староверия, протестантизма, толстовства, религиозно-философских обществ. Однако общий итог этого религиозного брожения “был очень скуден” [там же: 74-76]. Не смогла предложить что-то значительное и официальная церковь. Вместе с тем параллельно росла "массовая вера горожан в марксистскую квазирелигию” [там же: 74]. В итоге получилась “альтернативная Реформация”, или, как выражается автор, “полуреформацияполуотход от религии”, которые “сломали самые основания трехсотлетней власти династии Романовых и тысячелетней истории православной церкви, не сумевшей породить собственную Реформацию” [там же: 76]. На смену одной вере пришла другая - в социализм, марксизм-ленинизм, коммунизм и пр.

Истоки проблемы, предреволюционную духовную ситуацию в России С.В. Цирель описывает адекватно. Но вот вывод, на мой взгляд, спорен, ибо он основан на смешении базовых понятий. Попробую кратко пояснить. Существуют три синтетических формы общественного сознания - мифология, религия и идеология. Исторически они следуют одна за другой, но не разделены жесткой чертой: мифология в каких-то элементах сохраняется, а идеология в какой-то мере “удерживает” функции религии и мифологии, компонент “веры”. Но все-таки идеология - это не религия и не мифология. Она возникла как ответ на потребности новой эпохи и стремится опереться на данные науки. Кстати сказать, и сама наука не лишена ингредиента веры. Так, мы верим в существование электричества, хотя не знаем точно, что это такое, но можем наблюдать или испытывать его проявления. Наша 
вера, скажем, в закон Бойля-Мариотта или в любой другой закон природы так или иначе проверяется и корректируется практикой. И чтобы объяснить идейно-духовные истоки революции 1917 г. в России, по моему мнению, нет нужды прибегать к аналогии с европейской Реформацией, произошедшей в иную эпоху, в иной социально-культурной среде и давшей иные результаты.

О роли Антанты в Первой мировой войне и Февральской революции в России размышляет A.E. Гринин. Ход его рассуждений таков. Германская угроза России была мифом, а вхождение ее в Антанту ошибкой, что и подтвердили дальнейшие события. Англия и Франция просто “использовали” Россию в войне. Когда их положение на фронте было сложным, они шантажировали Россию обещаниями "проливов", но затем, когда военная ситуация для них становилась более сносной, они начинали склоняться к отказу от этих обещаний и поддерживать оппозицию в России против самодержавия, поскольку считали, что "думские министры окажутся в вопросах проливов и Польши сговорчивее царя”. Хотя к 1917 г. русская армия была готова к победе над Германией, Лондон и Париж к тому времени уже делали ставку на вступление в войну США, и необходимость в России как члене Антанты отпадала. Поэтому поддержку получили оппозиционные силы, выступающие против российского правительства. И это сыграло определяющую роль в падении самодержавия. А.Е. Гринин здесь солидаризуется с мнением германского канцлера Т. фон Бетман-Гольвега: “царь был... свергнут Антантой с помощью русских либералов” (цит. по [Гринин А. 2017: 120; см. также: 115, 116, 117, 118]). Выходит, одной из целей поддержки Англией и Францией политической оппозиции в России было снижение активности последней на заключительном этапе войны. Лондон и Париж уже не были намерены делить лавры победителей с Россией, хотя в выходе России из войны должна была быть и действительно была заинтересована лишь Германия. Но основной изъян концепции А.Е. Гринина, как представляется, кроется в его посыле, что решающий импульс революции (в данном случае Февральской) был дан извне. Разумеется, влияние политиков Антанты на политическую оппозицию в России имело место. Но главными движителем национальной революции выступают все-таки внутренние, а не внешние факторы.

A.И. Липкин в статье "Место Октября 1917 г. в истории России: революция или бунт?” на поставленный вопрос отвечает прямо и недвусмысленно: Октябрьская революция - это бунт. Хотя он не дает определения революции, но из текста ясно, что революции - это атрибут европейского социума, создававшего “договорную” политическую систему - правовое государство, демократию, разделение властей и пр. Незападные страны, в частности, Китай или Россия, создавали иную, “приказную” систему власти с “вертикальными, самодержавными институтами, в которых правами обладает только одна (верхняя) сторона" [Липкин 2017: 87]. Поэтому там происходят лишь периодические “бунты", “смуты”, которые "пошумев”, всякий раз вскоре восстанавливают (пусть в несколько измененном виде) прежнюю “приказную” структуру. Такова череда крестьянских восстаний в Китае, восстанавливавших в итоге имперскую власть, такова и эпопея семнадцатого года в России, которую автор ставит в параллель с Пугачевским бунтом [там же: 89].

Тема “бунта" или “смуты” в последнее время вызывает большой интерес у историков. Достаточно назвать книгу В.П. Булдакова [Булдаков 2010], ярко и подробно живописующую события 1917-1921 гг. в России, но менее продуктивную в плане теоретического осмысления. А.И. Липкин же в своей статье 
предлагает целую схему динамики социально-политических потрясений для России как результат воздействия или влияния на нее Европы. Схема такова: “победные бунты” (с начала XVII в.) задают “длинные циклы”, внутри которых происходят циклы более короткие. Последние состоят из “четырех тактов”: 1) "поражение от Запада" (с чего, скажем, началась шведская война Петра I), после чего следуют "либеральные реформы сверху" под лозунгом "Россия - это Европа"; 2) некоторые успехи в “сближении” более развитой Европы и "соответствующая победа”, сопровождающаяся, однако, озабоченностью правителя по поводу возросшей в ходе "либерализации сверху" свободы; 3) антилиберальные контрреформы; 4) “загнивание” и отставание (стагнация), а затем и очередное “поражение от Запада”. Данная последовательность, по словам автора, “воспроизводится достаточно строго” [Липкин 2017: 91-92].

Вряд ли, однако, можно признать “строгость” этой схемы. Куда-то делся XVII в. не только с его “бунташностью”, но и с попытками реформаторства. Сложно назвать преобразования Петра I, Анны Иоанновны, Елизаветы и даже Екатерины II либеральными. Почему-то в отдельный цикл выделяются два десятилетия эпохи Николая II, где было все одновременно - и “догоняние”, и реформы, и политические колебания то в одну, то в другую сторону. И уж совсем странной в следующем цикле является оценка событий 1991 г. как “очередного бунта" только на том основании, что в тех событиях имели место “массовые, протестные, против власти КПСС, настроения” [там же: 98]. Натяжкой выглядит и отнесение к "приказной системе" тех политических структур, которые установились в “лихие девяностые”. Нелегкое это дело - конструировать схемы...

Революция и бунт (смута) - все-таки разные вещи, хотя и не разделенные жесткой гранью. Бунты характерны прежде всего для добуржуазных обществ - что в Европе, что в Китае, что в Московской Руси, и их последствия действительно не выходили за рамки традиционных укладов. Революции же являлись политическим звеном (по большей части с буржуазным вектором) перехода от традиционного общества к индустриальному. Им, безусловно, сопутствовали проявления бунта (или смуты). Но в Европе, где предпосылки буржуазной формации были более развиты, эти проявления были слабее, в регионах “запоздавшей” модернизации - сильнее.

В России в годы революции масштабы бунта или смуты были связаны с феноменом, который можно обозначить как социально-культурное люмпенство (см. напр. [Хорос 1994: 113-131; 2010: 173-174]). Люмпенство - это не просто деклассированные элементы, пауперы, но и люди, оказавшиеся в ситуации отрыва от культурных корней, отпадения от прежних традиционных жизненных устоев и не включенные еще в иную, современную систему ценностей. Люмпенский контингент России резко увеличился в годы трех революций и гражданской войны и кратно усиливал атмосферу социального хаоса в стране. Хотя большевики и воспользовались люмпенскими элементами как тараном при завоевании власти, им же затем пришлось их жестоко подавлять.

Теперь еще об одном тексте - статье И.А. Ерохова "Русская революция идеальный предмет политической философии”. Она является, пожалуй, самой радикальной по своему посылу и замаху, безоглядной по отношению ко всем ранее высказанным мнениям о революции 1917 г. Если в других статьях данного выпуска журнала авторы все-таки соотносили революционные события или идеи с интересами крестьянства, рабочим движением, настроениями интеллигенции, позицией буржуазных кругов и т.П., то для Ерохова в этом нет нужды. Познание революции и политической борьбы в ее ходе, считает он, “становится делом чистой идеологии” [Ерохов 2017: 126]. 
Эта статья весьма нелегка для чтения - в ней много таких фраз, как “бинарная пара антитетичных перспектив", “Поведенческие спонтанности, вызванные бытийным напряжением сложившихся... условий жизни”, “идеология псевдоонтологизирует идеи" и т.П. Но если продраться через эти стилистические ухабы, то позиция автора достаточно определенна и ясна. Большевики, которых он, воспользовавшись формулой Ханны Арендт, называет “партией революционной политической богемы” [там же: 125, 128, 131, 138], так же как и другие радикалы-подпольщики, подвергались “смертельной опасности”, преследованиям со стороны царского режима, что подвигло их на борьбу с ним, на “бескомпромиссный ответный террор” [там же: 129]. В ситуации хаоса, разброда, когда “любая идеологическая наживка могла быть проглочена массой”, большевики проявили “идеологическую изобретательность”, “предложили простую стратегию нового мира, в которой все проблемы... старой жизни решались одним махом" [там же: 135]. Возглавив без колебаний “социально далекие от них и по духу, и по уровню образования народные массы” [там же: 132], большевики сумели в дальнейшем победить благодаря своему фанатизму, настойчивости и организованности и, таким образом, превратить политический переворот в октябре 1917 г. “в явление всемирно-исторического масштаба” [там же: 138].

Не думаю, что есть необходимость далее подробно разбирать данный этюд “политической философии”, попытку утвердить всесилие “идеологической изобретательности" большевиков, революционного сознания, творящего действительность, путь, который можно понять лишь задним числом, “из будущего” [там же: 143]. Могу лишь предположить, что И.А. Ерохов пренебрегает “навигатором" историзма, методологией адекватной исторической оценки идеологии Октябрьской революции и причин ее победы.

Наконец, о статье B.B. Лапкина "Послесловие к столетней годовщине: о политико-правовых и аграрных предпосылках Русской революции", которая в каком-то смысле стоит особняком, так как сочетает черты обеих групп рассмотренных статей. Также как, скажем, в статье А.Э. Айвазова и В.А. Беликова, ее автор прослеживает аграрные предпосылки революций 1917 г., начиная с крестьянской реформы 1861 г. Вместе с тем он тоже предлагает собственную схему, свое видение характера Революции (оперируя понятиями Русской революции, аграрной революции, революционной катастрофы), ее причин и последствий. Эта схема, как и в некоторых предыдущих случаях, безусловно, имеет предшественников.

В центре этой схемы - судьба русской поземельной крестьянской общины. Настолько в центре, что им используется, со ссылкой на Ю.С. Пивоварова, характеристика 1917 г. как “общинно-передельной революции” [Лапкин 2017: $214,239]$. Проследим коротко цепочку аргументов автора. Крестьянская община в России всегда была под жестким контролем государства. Общинно-передельная практика крестьянского землепользования “...(не путать с практикой соседской общины) вводилась властями, как правило, в качестве альтернативы подворному землевладению лишь по мере нарастания дефицита земель (роста малоземелья), причем зачастую довольно поздно - лишь в начале, а порою и в середине, а с начала и особенно с середины XIX в., вытесняя прежний обычай наследственного пользования земельными участками" [там же: 212-213]. В пореформенный период положение крестьянства (прежде всего самой многочисленной, бывшей частновладельческой его части) лишь усугубилось. По итогам Реформы крестьянство оказалось заперто в “общинно-передельном гетто” [там же: 211], “крестьянский 
мир стал сам для себя и сборщиком налогов и полицейским...” [там же: 226]. Сельчане испытывали “фискальное закрепощение”, усиливалось расслоение в крестьянской среде, катастрофически росло малоземелье, что разжигало настроения общинно-передельной революции и делало передельную крестьянскую общину господствующим элементом сельской жизни.

Столыпинские реформы явились попыткой дать крестьянам, до той поры выведенным “за рамки общегражданской юрисдикции” [там же: 230], возможность выбраться из пут общины, разрушить прежде пестуемую “сословную замкнутость крестьянского землевладения”, поддержать стремление части крестьянства к закреплению своих земельных наделов в частную собственность. Конкретным же поводом к реформам стал “беспрецедентный характер крестьянских беспорядков” в 1905 г., что и побудило “власть к радикальному пересмотру приоритетов аграрной политики”. Еще правительство Витте в ноябре 1905 г. приняло решение об отмене выкупных платежей и накопившихся недоимок, о повсеместной отмене института круговой поруки и переходе к индивидуальному налогообложению крестьян [там же: 234]. Но эффект реформы на конец 1916 г., что особо акцентируется автором, оказался неожиданным. Ссылаясь на данные, приводимые Б.Н. Мироновым [Миронов 2003: 481], автор приходит к выводу: “подавляющему большинству крестьянских дворов, желавших перейти от передельного к подворному землевладению, такая возможность была в конце концов предоставлена. Тем не менее те, кто накануне 1905 г. оставался верен передельно-общинному принципу землепользования (а эта категория составляла около 3/5 всех крестьянских дворов), в большинстве сохранили свои предпочтения вплоть до 1917 г. Столыпинские преобразования лишь проявили, сделали очевидным и политическим размежевание передельной и подворно-хозяйствующей деревни, создали предпосылки будущей 'гражсданской войны"” [Лапкин 2017: 236-237]. Более того, "в ходе этих преобразований был легализован раскол деревни..., конфликт между различными социальными стратами крестьянства выведен за рамки локальной крестьянской общины..., а конфликт общины и сторонников правового порядка стал силой, обрушившей Россию” [там же: 237]. И наконец, “наряду с сошедшимися в смертельном противоборстве российской городской цивилизацией, возникшей как результат петровских преобразований, и длительное время культивируемой властью общинно-передельной деревней на авансцену российской истории со всей решительностью вступила и “третья сила' - большевизм” [там же: 238].

В.В. Лапкин присоединяется к тезису Ю.С. Пивоварова о том, что в период революционной смуты лета-осени 1917 г. именно ставка большевистских лидеров (прежде всего Троцкого и Ленина) на “всемерное поощрение и разжигание общинно-передельной революции” [там же: 214] принесла им успех. Он задает вопрос: "Чем объяснить тот удивительный факт, что именно неумолимо влекомая обстоятельствами к своему окончательному разложению община в своем как бы 'предсмертном порыве' смогла стать мощнейшим, глобального масштаба фактором социальной эволюции?” [там же: 216]. Ответ, по-видимому, таков. Стихия общинной революции (реакция на аграрную реформу) "уже с весны 1917 г. используется большевиками в качестве своего рода тарана, с помощью которого была осуществлена значительная часть работы революционного низвержения старого социального порядка", а “Декрет о земле, принятый 8 ноября 1917 г., фактически легализовал уже свершившийся ‘на местах’ поворот к практике уравнительного землепользования, периодических переделов и поравнений, перечеркивавший 
все прежде достигнутые результаты столыпинской аграрной реформы" [там же: 239]. В результате “поглощенное переделами и поравнениями крестьянство привнесло в жизнь страны столько хаоса и беспорядка, что фактически нейтрализовало всякое сопротивление со стороны имущих городских слоев большевистской политике экспроприации промышленности, финансов и торговли. Это позволило осуществить окончательный разгром российского внутреннего рынка и вплотную подойти, в рамках политики военного коммунизма, к формированию режима единой политической и хозяйственно-распределительной монополии". Общинный уклад позволил “сгладить” остроту последствий развития рынка, смог "приспособиться и к крайне извращенному натуральному обмену времен военного коммунизма" [там же], а позднее косвенно способствовал появлению колхозной системы, которая “воспроизводила общинное землепользование, но лишенное всех признаков индивидуального хозяйства” [там же: 241]. Итогом явилось “формирование невиданного более нигде в мире чуда капитализма без рынка и буржсазии...”. "Полноценный выход из этого ценностно-культурного, социально-политического и экономического тупика не найден нашей страной и по сей день” [там же: 244].

В принципе здесь можно было бы возразить по многим пунктам. Община в России - это, по моему мнению, не продукт государства, так же как и земельные переделы внутри нее. Последние исторически шли по мере роста сельского населения, расширения крестьянских семей, а также наступления малоземелья. Сохраняя общину при запуске реформы 1861 г., правительство исходило не только из соображений удобства при сборе налогов и выкупных платежей, но и из понимания того, что крестьяне держатся за общинный институт как форму защиты собственных интересов (идея, которую подробно обосновывал при подготовке реформы близкий к царю Я.И. Ростовцев). Точно также общину можно рассматривать как "гетто” (“и сборщик налогов, и сам для себя полицейский”), а можно как орган самоуправления, каким он, наряду с земством, и был в пореформенную эпоху. Далее, большевики не делали никакой ставки на крестьянскую общину; в своих ранних работах Ленин расценивал ее как архаический институт, а в поздних работах переустройство деревни связывал не с общиной, а с кооперацией. Общинное крестьянство не только подстраивалось под порядки “военного коммунизма", но и протестовало, восставало против них, отсюда появился нэп и т.п. Да и вообще странно смотреть на общину в России как источник всех бед и катаклизмов гражданской войны.

Но это все-таки конкретные вещи, частности. Главное то, откуда они проистекают. А проистекают они, как мне представляется, из того, что “общинность”, ее “рабский дух”, этос для В.В. Лапкина - как бы средоточие, олицетворение того, что он принципиально не приемлет - коллективизма, уравнительности, солидарности и пр., короче, всего того, что было связано с советским социализмом, который для него (и не для него одного) является историческим тупиком. А это уже позиция, базовые ценности, с которыми человек подходит к оценке любых конкретных частностей, в том числе исторических реалий. Ценностный или мировоззренческий априоризм.

$$
* * *
$$

Значимость тематического номера журнала “История и современность” еще и в том, что читатель получает возможность панорамного и вполне адекватного охвата широкого спектра подходов и оценок, существующих сегодня в нашем обществе в целом, и в академической среде в частности, - к Октябрьской ре- 
волюции и ее долговременным последствиям. В этой палитре мнений можно выделить два основных кластера. Для одних Октябрь 1917 г. - это не только грандиозное по мировым меркам событие, но и закономерное явление, сложная историческая данность, в которой надо разбираться. А для этого требуется глубокий анализ породивших ее объективных и субъективных факторов, а также ее неоднозначных результатов, сформировавших целую (советскую) эпоху, не поддающуюся одномерным характеристикам (А.Э. Айвазов, В.А. Беликов, в какой-то мере Л.Е. Гринин и В.В. Лапкин). Другим эта революция видится главным образом в негативном свете - как разгул террора, уроки которого "не усвоены" до сих пор (Ю.С. Оганисьян), как псевдореформация или "квазивера” (С.В. Цирель), как безбрежный идеологический волюнтаризм (И.А. Ерохов) или исторический тупик (А.И. Липкин). Неприятие “революционного” и соответственно “советского” в этом подходе, как мне представляется, изначально, априорно. А чтобы избежать упреков в предвзятости, его сторонники конструируют ту или иную схему, дабы подтвердить теоретическими аргументами свою точку зрения. И в таких схемах, как правило, игнорируется или нарушается принцип историзма, когда прошлое представлено лишь “с одной стороны”, через призму чьих-то индивидуальных ценностных предпочтений.

Могут сказать: а разве возможно неаприорное постижение прошлого, без какого бы то ни было субъективизма, абсолютно беспристрастное в своих оценках? Безусловно, до конца объективным может быть только Господь Бог. Но это не значит, что не надо и невозможно стремиться к тому, чтобы суждения о прошлом были в научном плане максимально корректными. Принцип историзма включает не только способность историка взглянуть на обстоятельства с позиции изучаемых им исторических персонажей, но и в понимании сложности, многосторонности исторической реальности - и общественной, и личностной, а также ее альтернативности. Это, конечно, усложняет поиск адекватных оценок и суждений, но одновременно предостерегает от опасности односторонности, формулирования выводов и вынесения “приговоров” прошлому, так сказать, задним числом.

Повторю: оценка Октябрьской революции во многом определяется отношением к ее результатам, т.е. к советской эпохе, советскому социализму. Возможно, что время для настоящего разговора об этом все еще не пришло. Та эпоха, возможно, все еще недостаточно далека он нас - как для тех, кто связывает с ней что-то позитивное, так и для тех, кто стремится ее начисто перечеркнуть в своей непримиримости. Страсти еще не остыли. Тем не менее, я все же попробую кратко высказать свой взгляд на предмет - в порядке преамбулы к дальнейшим штудиям.

Полагаю, сегодня не надо пространно доказывать историческую обусловленность и закономерность революционных событий 1917 г. - этого не отрицают даже те, кто осуждает их (включая авторов рассмотренных статей). Предпосылки совершившегося вызревали долго, - в их ряду не только социальные проблемы деревни и города, не только тяготы мировой войны, но и накопленный за века крепостного права протестный потенциал. И неслучайно Октябрьская революция получила социалистическую направленность идеи социализма проходят через всю русскую общественную мысль, начиная с Герцена; они отнюдь не были простой идеологической фантазией.

В результате взрывные перемены начались как снизу, так и сверху, начался разлом общества по всем его сегментам, ведущий к хаосу и безвластию. В сложившейся ситуации большевики не узурпировали власть, а скорее подобрали 
ее, взяв на себя историческую ответственность за республику, а затем сумели одержать победу в гражданской войне и “собрать" страну из частей развалившейся империи. Последнее ставили в заслугу советской власти даже ее самые непримиримые оппоненты.

Однако деструктивное воздействие мировой войны, к которой Россия оказалась не готова ни в экономическом, ни в военном плане, резко обострило глубокий раскол, социокультурную рознь в российском обществе. Гражданское противостояние фактически началось еще до октября 1917 г., а затем только нарастало. Результатом явились не только хозяйственная разруха, но и потеря - в ходе взаимного истребления - обширного культурного слоя, необходимого для восстановления и строительства новой жизни. Все это втянуло власть большевиков в режим “чрезвычайщины”, в лихорадочный поиск срочных мер, в том числе с помощью разного рода утопических проектов. К тому же появление советского государства было враждебно встречено ведущими державами Запада. В постверсальской Европе росло напряжение, усугубленное мировым кризисом. Во всех партийных решениях того времени говорится об опасности войны - еще задолго до прихода Гитлера к власти. Жизнь диктовала необходимость ускоренной модернизации как промышленности, так и сельского хозяйства для отражения надвигающейся опасности.

Все это предполагало те или иные формы мобилизационной экономики. За годы нэпа восстановление народного хозяйства было лишь частичным. Требовалась форсированная индустриализация, создание мощной тяжелой промышленности и оборонных отраслей. Программа “сплошной” коллективизации была тесно увязана с такой индустриализацией, поскольку требовалось снабжать стремительно растущие города и грандиозные стройки продовольствием и рабочей силой. Поэтому нэп был свернут, планы пятилеток ужесточены, от стратегии кооперирования деревни (намеченной Лениным) пришлось отказаться, на естественное и органичное врастание крестьянства в новую жизнь, как мечталось, не было необходимого исторического времени.

Всякое форсирование, "пришпоривание” общественных процессов неизбежно ведет к конфликтам, просчетам, перегибам - тем более в суровом идеологическом и политическом климате той поры, с учетом склонности новых руководящих кадров к приказному администрированию, насаждению страха и насилия. Огромные издержки принесла коллективизация, проведенная при поддержке бедняцких и люмпенских элементов деревни и приведшая к депортации больших и наиболее эффективных в хозяйствовании страт крестьянства. И это было лишь частью маховика насилия и репрессий, который постепенно раскручивался в стране, начиная примерно с конца 1920-х годов и особенно в 1930-е годы.

Данный феномен можно объяснять по-разному - и “чрезвычайщиной”, и личной жестокостью партийных деятелей, прежде всего Сталина. И то, и другое, конечно, имело место, но не вполне объясняет причины таких масштабов и таких эксцессов насилия. Насилие шло не только сверху, но и снизу. Собственно сталинский террор направлялся прежде всего против политико-административной верхушки, неугодных управленцев, действительных или мнимых оппозиционеров. Но по-настоящему массовый террор, каким он был в тридцатые годы, стал, как мне представляется, своеобразным продолжением гражданской войны. Эта война не закончилась в 1921 г. и продолжалась в различных формах - бедные против “богатых” или мало-мальски имущих, “пролетарии” против “буржуев”, 
согласные против несогласных и т.П. Поэтому квалификация сталинизма как попытки модернизации “в условиях незакончившейся гражданской войны” [Марченя, Разин 2014: 625], на мой взгляд, является вполне оправданной.

Настоящие, крупные революции, несмотря на историческую неслучайность такого ответа на назревшие проблемы социума, - это всегда тяжелое испытание для общества. Это всегда период ломки прежних институтов, законов, привычного уклада жизни, разрушения и насилия. Так было в свое время и в Англии, и во Франции. Последствия этих катаклизмов могут сказываться достаточно долго. В России социальные и политические потрясения были особенно суровыми и продолжительными. Такие времена можно сравнить с тектоническими сдвигами в обществе, когда инерция радикализма захватывает и верхи, и низы, и тем самым сужается возможность выбора, принятия разумных или оптимальных решений. Какие-то конкретные альтернативы, наверное, не исключены, но они вряд ли могли бы “отменить” общий характер таких суровых и кризисных эпох.

Обращаясь к реальности того времени, любой непредвзятый взгляд обнаружит там не только беззакония и жестокости. Наряду с этим - точнее было бы сказать: несмотря на это, вопреки этому - он обнаружит в ней элементы искреннего идеализма, энтузиазм в труде, веру в будущее и в правоту общественно значимых целей, тягу к знаниям, науке, "разумному, доброму, вечному”. Почему это могло сочетаться и сочеталось? Обществу была предложена идеология (пусть в специфической, марксистской форме), которая была ориентирована на поиски "правды” и достижение социальной справедливости на путях коллективизма, “общинности”. И в целом это соответствовало ценностям российской цивилизации, формировавшимся веками. Эти идеалы так или иначе подкреплялись делами - социальной политикой (пусть с элементами уравнительности), добротной системой образования (пусть и идеологизированной) - и потому работали. Иначе не понять, почему десятки миллионов людей в тяжелейшие годы Великой отечественной войны поднялись на защиту не только своей Родины, но и советского строя. Или не объяснить выдающиеся достижения советской науки и культуры “длинных” шестидесятых годов.

Но затем - где-то в середине семидесятых - стала сдавать, если так можно выразиться, энергетика общества, прошедшего столько испытаний с самого начала двадцатого века. Росли усталость и раздражение людей от товарного дефицита, которому не было видно конца. Системе требовался, что называется, капремонт, серьезные реформы - как политические, так и, особенно, экономические. Но партийно-советские верхи не были к ним расположены. Отказ от так называемого культа личности стал для них лишь способом обеспечить собственную безопасность, которая при порядках сталинского типа постоянно подвергалась бы рискам. В результате советская номенклатура постепенно утрачивала динамизм, тормозила любые попытки обновления. Претерпевала девальвацию и социалистическая идеология. В этих условиях у части властной элиты возник соблазн трансформировать по существу бесхозную "общенародную собственность", которой они фактически распоряжались, в собственность “собственную”. Механизмов, которые могли бы им в этом помешать, социализм не выработал.

И тем не менее сегодня нам не след отказываться от советского прошлого, от того, что Россия стала первой в мире страной социализма. Он складывался не так, как его представляли себе Маркс, Энгельс и даже Ленин. Ошибки, просчеты, непредвиденные препятствия и драматические повороты на этом пути были неизбежны. И тем не менее в процессе социалистической модернизации 
в СССР был найден ряд перспективных для своего времени - и я бы прибавил, для теории социализма в целом - решений. Это - плановая система, оригинальная методика составления межотраслевых балансов, разработанная ЦСУ СССР еще в 1923-24 годах и сегодня используемая в той или иной мере во многих странах мира. Это - двухканальная система денежного обращения (наличные и безналичные деньги), что позволяло разделить потребительскую и инвестиционную сферы, минимизировать транзакционные издержки и контролировать инфляционные процессы. Это - развертывание системы массового образовании, что способствовало вертикальной мобильности в обществе и развитию науки, техники и культуры. Это - социальная политика, которая при всех крайностях уравнительности и скудости тогдашних условий жизни была ориентирована на то, что позже получило название "социальное государство”.

Советский социализм - это лишь часть истории мирового социалистического движения, которое далеко не вчера началось и отнюдь не завтра завершится. Так что тема, как говорится, не закрыта. Конечно, времена пришли другие, и соответственно как теория, так и практика социализма нуждаются в обновлении. Привычные формулы уже не работают. Скажем, деление социума на буржуазию, пролетариат, крестьянство и интеллигенцию не подходит для современного общества. Оно сегодня более дробно и сложно, а указанные категории изменились по содержанию. Не идет речь и о “диктатуре пролетариата". Назрел новый серьезный анализ явления “казарменного коммунизма”, на опасность которого столь выразительно указывали Оруэлл, Достоевский (а до них еще и Маркс): при попытках построения социализма почему-то одни оказываются равны, а другие "равнее”. Для глубоких обобщающих выводов в такого рода поиске будет необходим учет совокупного опыта истории социализма, включая “реальный социализм” советского типа.

Наконец, - и этим естественно будет закончить данную статью, - сбалансированное, освобожденное от крайностей отношение к советскому периоду поможет более ясно разглядеть природу породившей(их) его революции(ий) семнадцатого года. Но для этого потребуется отнестись к столь сложному сюжету, базируясь на принципе историзма, а не на априоризме и изначально сложившемся субъективном неприятии.

Айвазов А.Э., Беликов В.А. 2017. Экономические предпосылки Октябрьской революции 1917 г. - История и современность. № 2. С. 145-161. Доступ: https://www. socionauki.ru/journal/articles/1313856/ (проверено 15.09.2018).

Булдаков В.П. 2010. Красная смута. Природа и последствия революционного насилия. М.: РОССПЕН. 376 c.

Гринин А.Е. 2017. Антанта, Первая мировая война и Февральская революция 1917 г.: о некоторых аспектах исторических взаимосвязей. - История и современность. № 2. C. 100-123. Доступ: https://www.socionauki.ru/journal/articles/1313724/ (проверено 15.09.2018).

Гринин Л.Е. 2017. Российская революция в свете теории модернизации. История и современность. № 2. С. 22-57. Доступ: https://www.socionauki.ru/journal/ articles/1313670/ (проверено 15.09.2018).

Ерохов И.А. 2017. Русская революция - идеальный предмет политической философии. - История и современность. № 2. С. 124-144. Доступ: https://www.socionauki. ru/journal/articles/1319813/ (проверено 15.09.2018).

Лапкин В.В. 2017. Послесловие к столетней годовщине: о политико-правовых и аграрных предпосылках Русской революции. - История и современность. № 2. С. 211-246. Доступ: https://www.socionauki.ru/journal/articles/1313955/ (проверено 15.09.2018). 
Липкин А.И. 2017. Место Октября 1917 г. в истории России: революция или бунт? - История и современность. № 2. С. 86-99. Доступ: https://www.socionauki.ru/ journal/articles/1313710/ (проверено 15.09.2018).

Малинова О.Ю. 2018. Коммеморация столетия революции(й) 1917 года в РФ: анализ стратегий ключевых мнемонических акторов. - Полис. Политические исследования. № 1. С. 9-25. https://doi.org/10.17976/jpps/2018.01.02

Миронов Б.Н. 2003. Социальная история России периода империи (ХVIII - начало ХХ в.): Генезис личности, демократической семьи, гражданского общества и правового государства. Т. 1. СПб.: Дм. Буланин. 548 с.

Миронов Б.Н. 2010. Благосостояние населения и революции в имперской России: XVIII - начало ХХ века. М.: Новый хронограф. 911 с.

Миронов Б.Н. 2014. Российская империя: от традиции к модерну. Т. 3. СПб.: Дмитрий Буланин. 992 с.

Марченя П.П., Разин С.Ю. 2014. Иосиф Сталин как крестьянский царь: Второй Международный круглый стол "Сталинизм и крестьянство” (Заседание № 4 теоретического семинара “Крестьянский вопрос в отечественной и мировой истории”). Сталинизм и крестьянство: сборник научных статей и материалов круглых столов и заседаний теоретического семинара “Крестьянский вопрос в отечественной и мировой истории”. Под ред. П.П. Марченя, С.Ю. Разина. М.: Издательство Ипполитова. С. 615-708.

Оганисьян Ю.С. 2017. Октябрьская революция и террор. Исторический очерк с выходом на современность. - История и современность. № 2. С. 162-190. Доступ: https://www.socionauki.ru/journal/articles/1313869/ (проверено 15.09.2018).

Хорос В.Г. 1994. Русская история в сравнительном освещении. М.: Аспект-пресс. 191 с.

Хорос В.Г. 2010. О причинах российской революции. - Полис. Политические исследования. № 5. C. 161-175. URL: http://www.politstudies.ru/files/File/2010/5/14.pdf (проверено 05.09.2018).

Хорос В.Г. 2016. Исторический оптимизм Б.Н. Миронова. - Былые годы. Т. 41-1. № 3-1. C. 848-856. URL: https://docplayer.ru/34876888-Bylye-gody-3-1-rossiyskiy-istoricheskiy-zhurnal.html (проверено 05.09.2018).

Цирель С.В. 2017. Революция 1917 г. как альтернатива несостоявшейся Реформации. - История и современность. № 2. С. 58-85. Доступ: https://www. socionauki.ru/journal/articles/1313680/ (проверено 15.09.2018).

Huntington S.P. 1968. Political Order in Changing Societies. New Haven, London: Yale University Press. 488 p.

DOI: $10.17976 /$ jpps/2018.06.11

\title{
THE PRINCIPLE OF HISTORICITY AND THE A PRIORI KNOWLEDGE: POLITICO-ANALYTICAL RETROSPECTIVE OF THE RUSSIAN REVOLUTION
}

\author{
V.G. Khoros ${ }^{1}$ \\ ${ }^{1}$ Primakov National Research Institute of World Economy and International Relations (IMEMO), \\ Russian Academy of Sciences. Moscow, Russia
}

KHOROS Vladimir Georgievich, Dr. Sci. (Hist.), Head of the Center for Development and Modernization Studies, Primakov National Research Institute of World Economy and International Relations, Russian Academy of Sciences. Email: khoros@imemo.ru

Khoros V.G. The Principle of Historicity and the A Priori Knowledge: Politico-Analytical Retrospective of the Russian Revolution. - Polis. Political Studies. 2018. No. 6. P. 155-171. https://doi.org/10.17976/jpps/2018.06.11

Received: 23.04.2018. Accepted: 18.07.2018

Abstract. The article gives comment on the special issue of the "History and Modernity" journal devoted to the centenary of the Russian 1917 revolution. The articles published in this issue reflect the public opinions as well as estimations of academic circles on the subject, on the whole. There are two main approaches. First, vision of and accent on objective reasons of revolution which, to a significant extent, the preceding 
investigations pointed out; and second, a quest of new interpretations predominantly connected with negative characteristics of the revolution. But the latter approach often ignores the principle of historicity, that is, why actors in the past thought and acted in such or another way in specific historical situation and only on the base of this adequate understanding a scientific or moral estimation is possible. The concept of the October revolution much depends on estimation of its results, that is, the Soviet epoch in the Russian history. The author presents his own explanation of the Soviet period in the context of world-wide evolution of the socialism. His main idea is to understand the Soviet socialism as many-sided phenomenon where to see only negative aspects would be wrong. The same approach is necessary in case of 1917 revolution(s).

Keywords: Russian 1917 revolution; socialism; ideology; principle of historicity; a priori knowledge Soviet epoch.

\section{References}

Ayvazov A.E., Belikov V.A. The Economic Prerequisites of the October 1917 Revolution. - Istoriya i sovremennost'. 2017. No. 2. P. 145-161. (In Russ.) URL: https://www.socionauki.ru/journal/articles/1313856/ (accessed 15.09.2018).

Buldakov V.P. Krasnaya smuta. Priroda i posledstviya revolutsionnogo nasiliya [The Red Troubles. The Nature and Consequences of Revolutionary Violence]. Moscow: ROSSPEN. 2010. 376 p. (In Russ.)

Grinin A.E. The Entente, World War I and the February 1917 Revolution: on Some Aspects of Historical Links. - Istoriya i sovremennost’. 2017. No. 2. P. 100-123. (In Russ.) URL: https://www.socionauki.ru/journal/ articles/1313724/ (accessed 15.09.2018).

Grinin L.E. The Russian Revolution in Terms of Modernization Theory. - Istoriya i sovremennost'. 2017.

No. 2. P. 22-57. (In Russ.) URL: https://www.socionauki.ru/journal/articles/1313670/ (accessed 15.09.2018).

Huntington S.P. Political Order in Changing Societies. New Haven, London: Yale University Press. 1968. 488 p.

Khoros V.G. Russkaya istoriya v sravnitel'nom osveschenii [The Russian History in Comparative Perspective]. Moscow: Aspect Press. 1994. 191 p. (In Russ.)

Khoros V.G. On the Causes of the Russian Revolution. - Polis. Political Studies. 2010. No. 5. P. 161-175. (In Russ.) URL: http://www.politstudies.ru/files/File/2010/5/14.pdf (accessed 05.09.2018).

Khoros V.G. The Historical Optimism of Boris Mironov. - Bylye Gody. 2016. Vol. 41-1. No. 3-1. P. 848-856. (In Russ.) URL: https://docplayer.ru/34876888-Bylye-gody-3-1-rossiyskiy-istoricheskiyzhurnal.html (accessed 05.09.2018).

Lapkin V.V. An Afterward to the Centenary: on the Political, Legal, and Agrarian Prerequisites of the Russian Revolution. - Istoriya i sovremennost'. 2017. No. 2. P. 211-246. (In Russ.) URL: https://www. socionauki.ru/journal/articles/1313955/ (accessed 15.09.2018).

Lipkin A.I. The Place of October 1917 in the History of Russia: a Revolution or a Rebellion? - Istoriya i sovremennost'. 2017. No. 2. P. 86-99. (In Russ.) URL: https://www.socionauki.ru/journal/articles/1313710/ (accessed 15.09.2018).

Malinova O.Yu. The Commemoration in Russia of the Centenary of the 1917 Revolution(s): Analysis of Strategies of the Key Mnemonic Actors. - Polis. Political Studies. 2018. No. 1. P. 9-25. (In Russ.) https:// doi.org/10.17976/jpps/2018.01.02 (accessed 15.09.2018).

Mironov B.N. Sotsial'naya istoriya Rossii perioda imperii (XVIII - nachalo XX v.): Genezis lichnosti, demokraticheskoi sem'i, grazhdanskogo obshchestva i pravovogo gosudarstva [Social History of Russia during the Period of the Empire (18 $18^{\text {th }}-$ early $20^{\text {th }}$ century): The Genesis of the Individual, Democratic Family, Civil Society and the Rule of Law]. Vol. 1. Saint Petersburg: Dmitriy Bulanin Publishers. 2003. 548 p. (In Russ.)

Mironov B.N. Blagosostoyanie naseleniya i revolutsii v imperskoi Rossii: XVIII - nachalo XX veka. [The Welfare of Population and Revolutions in Imperial Russia: $18^{\text {th }}-$ the Beginning of $20^{\text {th }}$ Century]. Moscow: Novyi Hronograf. 2010. 911 p. (In Russ.)

Mironov B.N. Rossiiskaya imperiya: ot traditsii $k$ modernu [The Russian Empire: from Tradition to Modernity]. Vol. 3. Saint Petersburg: Dmitriy Bulanin Publishers. 2015.990 p. (In Russ.)

Marchenya P.P., Razin S.Yu. Iosif Stalin kak krest'yanskii tsar': Vtoroi Mezhdunarodnyi kruglyi stol "Stalinizm i krest'yanstvo". (Zasedanie No. 4 teoreticheskogo seminara "Krest'yanskii vopros v otechestvennoi i mirovoi istorii"). [Joseph Stalin as the Peasant Tsar: Second International Round Table "Stalinism and the Peasantry" (Session No. 4 of the theoretical seminar "The Peasant Question in the Domestic and World History")]. - Stalinizm i krest'yanstvo. Sbornik nauchnykh statei i materialov kruglykh stolov i zasedanii teoreticheskogo seminara "Krest'yanskii vopros v otechestvennoi i mirovoi istorii". Pod red. P.P. Marchenya, S.Yu. Razina [Stalinism and the Peasantry. Collection of Scientific Articles and Materials of Round Tables and Meetings of the Theoretical Seminar "The Peasant Question in the Domestic and World History". Ed. by P.P. Marchenya, S.Yu. Razin]. Moscow: Izdatel'stvo Ippolitova. 2014. P. 615-708. (In Russ.)

Oganisian Yu.S. The October Revolution and Terror. A Historical Essay with Output Concerning Modernity. - Istoriya i sovremennost’. 2017. No. 2. P. 162-190. (In Russ.) URL: https://www.socionauki.ru/ journal/articles/1313869/ (accessed 15.09.2018).

Tsirel S.V. The Revolution of 1917 as an Alternative to the Failed Reformation. - Istoriya i sovremennost'. 2017. No. 2. P. 58-85. (In Russ.) URL: https://www.socionauki.ru/journal/articles/1313680/ (accessed 15.09.2018).

Yerokhov I.A. Russian Revolution as an Ideal Subject for Political Philosophy. - Istoriya i sovremennost’. 2017. No. 2. P. 124-144. (In Russ.) URL: https://www.socionauki.ru/journal/articles/1319813/ (accessed 15.09.2018). 